\title{
The Controversy of the Term Arab/s throughout Time
}

\author{
Huda Al-Matrafi \\ Foreign Languages Department, Taif University, Taif, KSA \\ Email: dr.hudamatrafi2014@hotmail.com
}

How to cite this paper: Al-Matrafi, $\mathrm{H}$. (2018) The Controversy of the Term Arab/s throughout Time. Open Journal of Social Sciences, 6, 83-92.

https://doi.org/10.4236/jss.2018.61006

Received: December 13, 2017

Accepted: January 15, 2018

Published: January 18, 2018

Copyright (C) 2018 by author and Scientific Research Publishing Inc. This work is licensed under the Creative Commons Attribution-NonCommercial International License (CC BY-NC 4.0). http://creativecommons.org/licenses/by-nc/4.0/

\begin{abstract}
The Arab world is the West's closest neighbour across the Mediterranean and the Atlantic Oceans, yet little is known of it or of its peoples and their origins. Despite many texts that have been written on the Arab world, the term "Arab" and the origins of Arabs, issues remain that continue to generate debates and disputes. Many works and studies have examined the term "Arab/s" and have focused on defining the term "Arab/s" in various time periods; however, this paper discusses the controversies that surround these issues. In other words, it examines both the opposed and shared Western and Eastern perspectives of the term throughout time. The paper focuses on the origins of the term and the ways new connotations have developed throughout time due to political and social issues; however, it was concluded that regardless of the number of controversies or the number of new connotations that have developed, the term Arab/s still refers to a group of people with a shared language and a shared heritage.
\end{abstract}

\section{Keywords}

Definition, History, Arab, Controversies, Language

\section{Introduction}

"Only a small proportion of the lore of the Arabs has come down to you. Had it reached you in its entirety, much scientific and literary knowledge would have been yours."

Since the eighth century, several Muslim scholars and scientists, such as Abu' Amr al-'Ala', have claimed that the non-Arab world knows little of the Arabs ${ }^{1}$ The translation of this passage is mine. It is spoken by the famous Muslim philologist, Abü'Amr ibn al-'Alā', and is cited in Tabaqātfuhūl al-shu' arā' [Classes of the Eminent Poets] by the Iraqi scholar and a pioneer in literary criticism, Mahammad Ibn Sallam Al-Jumahi (1974, pp. 756-845). 
and their origins. This belief still exists despite the numerous texts that have been written on the subject. When there is much knowledge to consider, there are undoubtedly a large number of different views and arguments. Due to these divergences, both the opposed and the shared views of the numerous texts have been examined to answer the following questions: What does the term "Arab" mean? Who is an Arab? Throughout time, does the term still contain similar connotations? Thus, this paper discusses three important issues: the various definitions of the term "Arab/s" throughout time, the controversies of the Arabs' origins and how the term has changed over the second half of the twentieth century and in the new millennium. Hence, this paper introduces both Western and Eastern concepts of the term "Arab/s" throughout history. In other words, it explores the various debates and disputes that surrounds such issues by introducing both the opposed and shared Western and Eastern perspectives of the term "Arab" throughout time.

\section{Origins of the Term "Arab"}

The term "Arab" is problematic, obscure and ambiguous; however, although scientists, linguists and historians have various views concerning the origin and meaning of the term, their definitions share some features. For example, Alusi (1924) [1], a well-known Iraqi scientist, claimed that the term refers to people who speak the Arabic language and who are the children of Arabs, whose homes were built on Arabian lands until the emergence of Islam and who then dispersed throughout the lands. ${ }^{2}$ In addition, the Syrian geographical writer and linguist Al-Hamawi (1957) [2] declared that the term "Arab" refers to all who live in the Arabian Peninsula and speak its people's language. In other words, both Alusi and Al-Hamawi claimed that there is an interconnection between Arab identity and the Arabic language.

Moreover, according to Alusi, some linguists have asserted that the term "Arab" is derived from the verb "Yarub", meaning the eloquence of speech, which refers to the Arabs, who were known for their eloquence [1]. On the other hand, other scholars, such as the Arabic lexicographer Ibn Mandoor (1955) [3] claimed in Lisan al-Arab (The Arab Tongue) that the term is the root word for the verb "Yarub". He argued that the verb "Yarub" is the one, which is derived from the term "Arab", meaning to express one's thoughts. In addition, scholars have claimed that the terms "Arab" or "Arabic" are linguistically correlated with the word "Abri", which means "Hebrew", because they are derived from the same root, "Abar", and indicate one meaning: "cross" or "pass". The Russian historian Carmichael (1969) [4] asserted that "though the origin of the word 'Arab' itself remains somewhat obscure, some authoritative opinions tend to regard it as probably derived from an ancient Semitic root implying nomadism, i.e. 'abar' or 'pass', from which the word 'Hebrew' too is ultimately to be derived".

${ }^{2}$ This is my translation. Bulug al-arabfi ma'rifatahwal al-arab [Achieving the Aims to know the Conditions of Arabs] is one of Alusi's most famous books. In this book, Alusi discussed the pre-Islamic Arabs and their history, relying heavily on their poetry for knowledge. 
This is because the Arabs and the Hebrews were originally from the Bedouin and nomadic traditions, who did not settle in one place and continuously migrated with their camels and livestock searching for water and herbage.

Thus, it can be said that both terms, "Arabi" (Arabic) and "Ibri" (Hebrew), mean "Bedouin", an inhabitant of the desert [5]; however, throughout history this definition has only been used in reference to Arabs. Patai (2002) [6] a Jewish professor, stated that in the "first historical appearance of the Arabs they are associated with camels-evidently they were camel-herding desert Bedouins-and throughout the ensuing twenty-eight centuries, the association between Arabs and the desert has never ceased". Although some consider this a biased image, it is evident in many works, whether written or observed. This is clearly and thoroughly emphasized in Reel Bad Arabs: How Hollywood Vilifies a People by Shaheen (2002) [7].

Historically speaking, according to the Iraqi academic writer Ali (1993) [8], the oldest text in which the term "Arab" is found dates back to the reign of the Assyrian king Shalmanassar the III (824-859 BC). ${ }^{3}$ Ali claimed that in the Assyrian inscriptions of $853 \mathrm{BC}$, the term "Arab" also indicates Bedouinism or nomadism. In the Assyrian inscriptions, various readings were found for the word "Arab", such as "Aribi”, “Arbi”, "Urbu”, “Arabi”, “Arub”, "Arubu” and "Aribu”. The term can be found in Persian texts from the sixth century BC in which it also carried the same meaning as "Bedouin". In addition, the term also appears in the Old Testament, again referring to Bedouins and nomads who lived in tents. This definition was repeated in other Books of the Bible, such as Isaiah and Jeremiah. Patai (2002) [6] explained that "Isaiah (13:20) refers to the Arab pitching his tent, which presupposes a nomadic, desert-dwelling existence". The meaning here does not indicate the nationality of a specific race; rather, it means the desert, the land of isolation and alienation. As for the Talmud, the words "Arab", "Arbeem" and "Arbaim" mean "nomads". Namely, they have the same meaning that is stated in the Testaments. In both books, the term "Arabic" is also often synonymous with the word 'Ishmaelite' in reference to the Prophet Ishmael because the Arabs are believed to be the descendants of the prophet. This issue is illustrated in the following section, which focuses on the origins of the Arabs.

Moreover, in the previously mentioned work, Ali (1993) [8] declared that in the late sixth century BC, the term "Arab" and the discourse on Arabs appear in the writings of the Greeks. He believes that Aeschylus (456-525 BC) was the first Greek who mentioned the term "Arabs" while discussing the Persian king Akzrksys I (465-486 BC), who attacked the Greeks in their lands with an army that was led by a distinguished Arab officer [8]. He added that the same term was mentioned in Herodotus' (430-484 BC) second book, which refers to the Arabs as a group of people from Arabia, and the term "Arabie" is added, which indicates the "desert" and the Arabian Peninsula, as is also explained in Encyclopaedia Biblica [9]. ${ }^{4}$

${ }^{3}$ The translation is mine. The historical information in this part is derived from Ali (1993).

${ }^{4}$ Herodotus' Book II (Euterpe) is about Egypt, Egyptians and their customs. 
For the pre-Islamic era, which the Arabs call "the Jahiliyah period", a term usually defined as "time of ignorance" [10], only one text was found for the North Arabians in the Namara Inscription in AD 328 in which the term "Arab" was mentioned, also meaning "Bedouin". ${ }^{5}$ Although these inscriptions exist, the North Arabians produced no system of writing until the time of Muhammad' [10]. In fact, they have based their culture on an oral history. For the Southern Arabians, the term "Arab" was never mentioned except in the form "Aarab", which was recognized with the arrival of the northern nomads into the southern part of Arabia and which also has the same meaning as Bedouin. This indicates that this was a period in which ignorance was a prevalent feature in Arabia because "Arabia had no dispensation, no inspired prophet, and no revealed book" yet [10].

Thus, when Islam arrived and the Qur'an was revealed, there were three forms of the root word "Arab": "Uraban", "Aarab" and "Arabi". ${ }^{6}$ Beginning with the term "Uraban", it describes a woman who is lovable and delightful to her husband. The word "Aarab" appears ten times in the Qur'an, and as with previous definitions, it means "Bedouins". Eventually, the Qur'an settled the matter, as the word "Arabi" appears in its verses eleven times, ten of which describe the language in which the Qur'an was revealed and one which describes the Prophet Muhammad's character as being an Arab. It states "And if we had sent this as a Qur'an in a foreign language (other than Arabic), they would have said, 'Why are not its verses explained in detail (in our language)? What! (A Book) not in Arabic and (the Messenger) an Arab?" [11]. This verse again emphasizes the connection between the Arabic language and Arab identity.

Hence, it is clear that throughout history, the word "Arab" has had different connotations with no conclusive definition. First, it meant "Bedouin" or "nomad". Later, it referred to those who speak the Arabic language. Patai (2002) [6] stated:

"The foundation of Islam by the Prophet Muhammad (570-632) and the Islamization of Arabia during his lifetime marked the beginning of the large-scale Arab expansion outside the Arabian Peninsula and the Syrian Desert. From this time on, the term Arab assumed a second meaning: it came to denote all the peoples who, after having been converted to Islam, gave up their ancestral languages and adopted Arabic instead."

In fact, a third meaning came into existence because the word "Arab" became coexistent with the word "Muslim", as the Arabic language spread with Islam. As Patai (2002) [6] asserted, the Arabs "consider themselves the core of the Muslim nations, since they were the originators of Islam and those who spread it in the ${ }^{5}$ The Namara Inscription is the most eminent Arabic text because it is written in pure standard Arabic. It was discovered by Reme Dussaud in 1901 in the Namara area near Damascus. It was inscribed on the gravestone of Emr'aoo Al Qias, an Arab king who died in AD 328. Today, this stone is in a museum in Paris.

${ }^{6}$ The Qur'an is a constitution that is the basis for the existence of the Islamic nation politically, socially and linguistically for all times and places. Many Muslims believe that it purified humanity from the destruction and the corruption of the earlier phases and that it made all human beings equal, regardless of their origins. 
world". Consequently, many Arabs are referred to as Muslims. It is significant to note that although there is an overlap between the terms "Arab" and "Muslim", they are distinct. Shora (2009) [12] explained, "While most Arabs are Muslims, only $20 \%$ of Muslims are Arabs"; however, this inconsistency is clear in modern society. Reimers (2005) [13] noted:

"Many Americans automatically assume that all Middle Easterners are Arabs, whom they believe to be Muslims. Particularly after the terrorist attacks in the United States on September 11, 2001, Muslims and Arabs were often conflated in the eyes of many Americans, in part because the terrorists were known as fundamentalist Muslims, or 'Islamists'."

This confusion prompts the question: who are the Arabs? To answer this, it is important to provide a brief overview of their origins.

\section{The Origins of the Arabs}

There has been considerable controversy concerning the definition of "Arabs", their origins, their homes, their lands and how they emerged. One contribution towards the divergences in discourses is that pre-Islamic history was surrounded by vagueness because the Arabs of that period had no written records, as they were a society that was based on an oral culture. Without a clear or written methodology to follow, the Arabs of this period were a corrupted and demoralized people of many tribes, where each tribe had its own authority. They worshipped idols, fought one another and degraded women ${ }^{7}$; however, it is significant to note that although the era is known for its ignorance, there are laudable features, such as the Arabs' intelligence, generosity, hospitality, courage and love and eloquence illustrated in poetry, which they used to transmit their culture. ${ }^{8}$

The Qur'an and the Sunna of the Prophet (the mode of the Prophet's life) eventually revealed many aspects of Arab history. From these two sources, the Qur'an and the Sunna, the identity of the Arabs becomes clear. Genealogists, scholars and historians, such as Ibn Duraid, Alusi and Ali, agree that the Arabs are from the Semitic race, and their origin can be traced to Shem, the son of Noah. These scholars claim that Shem is one of the three origins from which the nations subdivided: Shem, Ham and Japheth. According to these scholars, the Semitic people are divided into three groups: "the Perishing Arabs", "the Pure Arabs" and "the Arabised Arabs".

The Perishing Arabs (al Arab al Ba'ida) are those whose history is mostly unknown, except that they were punished and then perished for their disbelief, as mentioned in the Holy Books, such as the Qur'an. In other words, no Arab exists who originally belonged to these tribes. The Pure Arabs and the Arabised Arabs are the modern Arabs. They descended from two different ancestors: Qahtan and Adnan. ${ }^{9}$ The Qahtanian Arabs are called the Pure Arabs (al Arab al Ar'iba).

${ }^{7}$ For more information, see Abd Al-Halīm Abū Shaqqah (1999).

${ }^{8}$ The Arabs and their literature are illustrated in detail in Shawqi Daief (1960, pp. 141-143).

9The word "Qahtan" is identified with the Biblical "Joktan". 
They are the Semites who are the original Arabs and the descendants of Ya'rub bin Yashjub bin Qahtan and who inhabited Yemen as their homeland. The Adnani Arabs are referred to as the Arabised Arabs (al Arab al Musta'rabah). As indicated in the Qur'an and in historical books, they are the Semites who originally spoke Hebrew and the descendants of Ishmael, the son of Abraham. After Ishmael's marriage to a woman of an Arab tribe from Makkah, the heart of the Arabian Peninsula, Ishmael and his tribe adopted the Arabic language and thus became "Arabised".

Eventually, these descendants of the Semitic people were dispersed throughout the Middle East, which became the core area of the Arab world and the Arab culture, and "at the center of that culture is the Arabic language" [14]. Highlighting the issue of "Arabization" is highly significant. First, it emphasizes the connection of one's identity with his/her own language, whether it was original or adopted, as noted previously. Second, it stresses the concept that the settlement of the individual in an innovative culture and the adoption its language, which is a primary aspect of any culture, can transform one's identity.

Hence, as mentioned in the first part of this paper, many scholars have defined the Arabs by connecting them with the Arabic language. For example, Patai (2002) [6] suggested the acceptance of the recent definition by the Baghdadi critic, novelist and poet Jabra, who stated that an Arab is "anyone who speaks Arabic as his own language, and consequently feels as an Arab". Another similar definition was provided by a group of Arab researchers who met in Brussels in December 1938 and agreed that an Arab is anyone "who is Arab in language, culture and wila", that is one who has "nationalist sentiments" [15]. Their definition is closely related to that of the Arab critic Touma (1996) [16] who defined an Arab as "one who is a national of an Arab state, has command of the Arabic language, and possesses a fundamental knowledge of Arab tradition, that is, of the manners, customs, and political and social systems of the culture". Carmichael (1969) [4] asserted that what is necessary in defining the Arabs:

"is precision in referring to certain living individuals and communities who are called or call themselves 'Arab'. For most purposes, it will be found that the best criterion is language, with the exception of certain communities... such as the Jews and some other minorities. This 'definition' will comprise the Arabian Peninsula, Iraq, Syria, Jordan, Egypt, the Sudan (with the exception of the pagan Negro region in the south), Libya, Tunisia, Algeria, and Morocco."

Despite their differences, the Arabs of these countries consider themselves one nation. Patai (2002) [6] asserted that "in the Arab view... the Arabs constitute one nation, the Arab nation, and the division of the one Arab fatherland into numerous separate countries is but a temporary condition that sooner or later must be, will be, overcome". Thus, their unity is based on many things they have in common, such as history, culture and socio-political experiences, but mainly on the Arabic language. Accordingly, the notion that the Arabic language is a 
major characteristic in defining one's "Arab-ness" is a feature that should be noted. Thus, the term "Arab/s" can be defined as an expression that refers to people who speak Arabic and who live in the Middle East and the North and West coast of Africa. The Arabic language, despite the fact that it has faced and still faces many difficulties in being identified, became one of the six accredited languages in the United Nations in the second half of the 20th century: "December $18 \ldots$ is the day in 1973 when General Assembly approved Arabic as an official UN language" [17]. This is considered an achievement for the Arab world because language is the true gateway to the power of any civilization. Nevertheless, does the term "Arab/s" still hold the same definition? How is it defined in Western culture?

\section{The Term Arab in the Second Half of the $20^{\text {th }}$ Century and the New Millennium}

The word "Arab" was defined in the 1960s and 1970s in Roget Thesaurus as "roughneck, cad, clumsy, deceitful, naïve". These negative implications are explicitly written rather than implied. The connotations were changed only after considerable effort and pressure by Arab organizations in America [18]. In contemplating this issue, numerous questions arise. Why has the term "Arab" become an expression with so many negative concepts? Do these explanations highlight extreme racism? Some critics, such as Shaheen (1995) [19] who wrote Media Coverage of the Middle East, have argued that these images are a result of mass media, which is one of the largest influences on public perceptions. Its stereotypical descriptions of Arabs significantly affect how the public perceives and behaves towards them; however, other critics, such as the liberal Egyptian journalist Sharaf Al-Din (2014) [20], have agreed with these connotations and have suggested that the negative concepts of the term "Arab" have some basis. They contend that the stereotypical images attributed to the Arabs have been developed based on the world's accumulated experiences with them. In other words, they claim that the term "Arab" has unfortunately lost its essence, and the Arabs have lost their worth, identity and culture.

In the new millennium, due to dramatic political and social changes, the term "Arab/s" has burgeoned negative connotations, which has led to many prejudicial controversies despite the fact that the term is defined in a more appropriate manner in many dictionaries. For example, in the Cambridge English Dictionary, the word "Arab" is defined as "a person from Western Asia or North Africa who speaks Arabic as a first language". In the Merriam Webster Dictionary [21], the term is defined as "a member of the Semitic people of the Arabian Peninsula" and "a member of an Arabic-speaking people". The new prejudicial controversies became particularly evident after the $9 / 11$ attacks when the term began to receive negative and speculative attention. It is evident that the word "Arab", which had been correlated with eloquence, nomadism and Bedouinism in the past, is now perceived differently. The definition has become more incon- 
sistent and is often related to "extremism", "fanaticism", and "terrorism".

Two major reasons prompted the public's simplistic tendency, particularly the West, to associate the term "Arab/s" with negative expressions. First, many Arabs have committed the terror attacks that have taken place around the world. Second, the omissions and the stereotypical images circulating in public media have had an influence. This issue is well-expressed in many works, such as Being Arab: Ethnic and Religious Identity Building among Second Generation Youth in Montreal by Eid (2007) [22] and Reel Bad Arabs: How Hollywood Vilifies a People by Shaheen (2002) [7]. Consequently, the Arab world has recognized that fundamental changes are now necessary to regain its recognition and identity. For example, in The Arab World: Facing the Challenge of the New Millennium, Azzam (2002) [23] explores the fundamental changes that the Arab countries are currently experiencing. He explains that Arabs seek future prosperity and a dignified identity, particularly after the sectarian and political labels being forced upon them; however, this begs the question: are the old connotations of the term "Arab" applicable in identifying the Arab of the 21st century? There are some similarities with the earlier definitions; however, there are also differences. These variances are evident in the definition as a relationship between identity and language, for example, because many young Arabs living in the West do not speak their mother tongue. Consequently, how can one identify an Arab as an Arab if he/she does not speak Arabic? Second, the modernized Arab is no longer a nomad or a Bedouin travelling by camel from one place to another carrying a tent.

\section{Conclusions}

In conclusion, it is clear that the definition of the term "Arab" has had various connotations in both Western and Eastern worlds, some of which are negative and some of which are positive. However, despite the fact that it continues to remain under debate in both worlds and regardless of the number of the controversies and new connotations that have developed in regards to the term, it continues to refer to a group of people with shared language and heritage. In other words, the term is highly interrelated with the Arabic language and culture, which illustrates the homogeneity of Arabs. In an article entitled "Who is an Arab?", Watt and Cachia [24] assert:

"For many centuries, the basis of cultural affinity has been primarily religious. The religion of Islam provided the historical impetus creating the vast society to which the Arabs belonged. Intellectual disciplines associated with religion were the flywheel that maintained a steady, even movement. Within the community of Muslims, however, there was the still stronger bond of the Arabic Language. Arabic had a special status as the language of revelation. Arabic linguistic and literary standards remained remarkably homogeneous in the various regions of the Arab world and even in other Islamic provinces. This is the way it has been for centuries." 
Consequently, what is definite is that the term "Arab" is highly interconnected with the Arabic language and culture, which are among the richest and most important languages and cultures in the world. It is a language that represents Arabs' identities and lives and that reflects their profound beliefs, feelings and imaginations. However, it is significant to note that in this globalized era, in which Arab immigration to various Western countries has increased, further research should focus on new definitions and concepts that may occur in regards to the term Arab due to the rapid social and political developments.

\section{References}

[1] Alusi, M. (1924) Bulug al-arab fi ma'rifatahwal al-'arab. Dar AlkutubAlilmiah, Beirut, 52. [Translated]

[2] Al-Hamawi, Y. (1957) Mu'jam Al-Buldan. 4th Edition, Dar Sader, Beirut, 7. [Translated]

[3] Ibn Mandoor, M. (1955) Lisaan al-Arab. Dar Sadir, Beirut, 588. [Translated]

[4] Carmichael, J. (1969) The Shaping of the Arabs: A Study in Ethnic Identity. George Allen \& Unwin, London, 2-7.

[5] Wilson, C., and Gutierrez, F. (1995) Race, Multiculturalism, and the Media: From Mass to Class Communication. 2nd Edition, Sage Publications, London, 77-78.

[6] Patai, R. (2002) The Arab Mind. Hatherleigh Press, New York, 12-14 \& 260.

[7] Shaheen, J.G. (2002) Reel Bad Arabs: How Hollywood Vilifies a People. Olive Branch Press, New York.

[8] Ali, J. (1993) Al-Mufasaal fi Tareekh Al-Arab Qabil Al-Islam [The Details of the History of the Arabs before Islam]. 2nd Edition, Dar Alsaqi, Beirut, 7. [Translated]

[9] Cheyne, T.K. and Black, J.S. (1899) Encyclopaedia Biblica: A Critical Dictionary of the Literary, Political and Religious History. In: The Archaeology, Geography and Natural History of the Bible, Vol. 1, The Macmillan Company, New York, 273.

[10] Hitti, P. (1948) The Arabs: A Short History. Macmillan \& Co. Ltd., London, 20.

[11] Qur'an (2007) King Fahed's Collection Press. Madinah Al-Munawarah, 44.

[12] Shora, N. (2009) The Arab-American Handbook: A Guide to the Arab. In: Arab-American \& Muslim Worlds, Cune Press, Seattle, WA, 44.

[13] Reimers, D. (2005) Other Immigrants: The Global Origins of the American People. New York University Press, New York, 210.

[14] Barakat, H. (1993) The Arab World: Society, Culture, and State. University of California Press, Berkeley, 184.

[15] Polk, W. (1965) The United States and the Arab World. Harvard University Press, Cambridge, 253.

[16] Touma, H.H. (1996) The Music of the Arabs. Amadeus Press, Portland, 54.

[17] UN News Centre (1026) UN News Service.

[18] Aleedan, K. and Aldahsh, M. (2005) Research. The Image of the Muslims and Arabs in the World. http://www.islamtoday.net/bohooth/artshow-86-5366.htm

[19] Shaheen, J.G. (1995) Media Coverage of the Middle East: Perceptions and Foreign Policy. Annuals of the American Academy, 482, 160-175. https://doi.org/10.1177/0002716285482001010

[20] Sharaf Al-Din, N. (2014) The Meaning of the Word Arab in the West. 
https://www.youtube.com/watch?v=no-fRvOP

[21] Merriam Webster Dictionary. https://www.merriam-webster.com/dictionary/Arab

[22] Eid, P. (2007) Being Arab: Ethnic and Religious Identity Building among the Second Generation. McGrill-Queen's University Press, Montreal.

[23] Azzam, H. (2002) The Arab World: Facing the Challenge of the New Millennium. I.B. Tauris, London.

[24] Watt, W.M. and Cachia, P. (n.d.) Who Is an Arab? University of Pennsylvania: African Studies Centre. http://www.africa.upenn.edu/K-12/Who_16629.html 